Política e mercados - os sistemas políticos e econômicos do mundo

Por Charles E. Lindblom. Trad. de Ruy Jungman. Rio de Janeiro, Zahar, 1979. $443 p$

Política e mercados são dois elementos que se inter-relacionam nas sociedades do mundo de hoje, năo apenas nas ditas capitalistas, mas também nas chamadas socialistas. Esta é a idéia que permeia o livro mais recente do conhecido professor de economia e ciência política da Universidade de Yale. Charles E. Lindblom, o qual a Zahar achou por bem editar em língua portuguesa.

É claro que o papel dos dois fa tores acima citados varia entre os dois tipos de sociedade, bem como - para fugir a uma classificação meramente binária - entre sistemas poliárquicos, as chamadas democracias ocidentais, e sistemas autoritários, compreendendo a maior parte dos países socialistas bem como países não-socialistas sujeitos a regimes ditatoriais lo quadro da $p$. 185 é muito instrutivo para uma referência geral). Ao todo são quase 150 países, encontrando-se o maior número deles, principalmente os do chamado Terceiro Mundo, na faixa intermediária de "democracias relativas" ou paises em processo de abertura política.
A perspectiva em que se coloca o autor fica muito clara, se isto não ocorrer antes, quando se lê o capitulo 19, no qual se propõem dois modelos, que pretendem aproximar-se de concepções altamente sofisticadas da humanidade e seu destino. O modelo 1 , referente a uma sociedade orientada pelo intelecto, pressupõe que algumas pessoas possuem o dom da sapiência integral e, em função disso, são eleitas pelo destino para resolver todos os problemas da nação e, sobretudo, para orientar o processo de mudança política, econômica e social. O segundo modelo, ao contrário, é, por assim dizer, mais populista, pois parte do principio de que "todos sabem muito bem que são falíveis", como já assinalava no século passado o economista e cientista social Jornn Stuart Mill, no seu pouco conhecido, pelo menos no Brasil, On Liberty IDa Liberdadel.

Por falar em tiberdade, é muito oportuna a transcrição da nota de rodapé que aparece na p. 277:

"Reconheço que estou-me desviando de uma velha tradição que considera a liberdade como a distinção fundamental entre comunismo e poliarquias orientadas para o mercado. Embora a liberdade possa ser realmente a questão-chave na avaliação dos dois, nossa tarefa aqui não é a avaliação, mas o esclarecimento dos mecanismos fundamentais Isem os quais, poderíamos acrescentar, ninguém pode competentemente proceder a uma avaliaçãol. Além disso, os comunistas tipicamente alegam que apenas uma elite intelectualmente competente pode encaminhar uma sociedade para a liberdade. Tendo em vista só essa alegaçăo, é necessário começar com um exame da maneira como os dois tipos diferentes de sistema consideram a inteligência em sua aplicação às tarefas da organização social."

Mas qual a relação entre mercado e liberdade, já que a relaçăo entre política a liberdade é por demais conhecida? Um economista neoclássico tradicional diria que o mercado garante emprego racional dos recursos produtivos, respeitada a soberania decisória de consumidor que, por assim dizer, vota com seu dinheiro, pagando mais pelo que mais necessita ou valoriza. Este raciocínio, que teoricamente é questionável, coaduna-se perfeitamente com a ideologia do modelo 2 de Lindblom. Acontece que, como qualquer economista moderno deve saber, a alocação ótima da teoria tradicional pressupõe uma dada distribuição inicial de renda, além de postular sobre mecanismos de obtenção do necessário equilibrio entre oferta e procura (os leilões Walrasianos). Além disso, as condiçōes de mundo real, especialmente a presença de elementos monopólicos de maior ou menor grau, tiram o caráter impessoal atribuído pelos entusiastas da economia de mercado ao sistema de preços, quer os de bens e serviços finais, quer os de fatores de produção.

Não é, todavia, em função dessas objeções que os cientistas sociais do gabarito de um Lindblom devam abandonar, quer como profissionais ou simples cidadåos, uma postura liberal e humilde diante do mundo que os rodeia, de acordo com a filosofia do modelo 2. Depreende-se também da leitura do livro que as restrições teóricas e as imperfeições do mercado, especialmente, a presença de elementos monopólicos ou oligopólicos, esvaziam significativamente os defensores intransigentes da livreiniciativa, eternos guerrilheiros contra a intervenção do Estado na vida econômica.

Em suma, o autor é um crítico mordaz tanto do autoritarismo político e econômico como do pseudoliberalismo que termina favorecendo os mais fortes. Novas formas de governo precisam ser encontradas. Mesmo em poliarquias adiantadas, como a norteamericana, as coisas andam longe do satisfatório num cenário de problemas que se multiplicam num mundo complexo e interdependente. Afirma Lindblom em seu último capítulo: "Nos EUA, muitos cidadãos pensam que os problemas sociais estão superando de muito a capacidade do governo de resolvêlos. Estamos perdendo o controle. Muitos de nossos filhos não aprendem a ler. Os empregos são inseguros. O dinheiro não conserva seu valor. Em alguns dias, o ar é 
impróprio para a respiração. As ruas são inseguras. E há sempre a bomba - a probabilidade de um acidente, se não de uma guerra nuclear."

O trabalho de Charles Lindblom proporciona leitura agradável e de extrema utilidade para economistas, sociólogos, jornalistas e outros profissionais preocupados com a organização da sociedade. A lamentar apenas os cochilos do tradutor e/ou revisor. deixando uma ou outra frase inteligível, e a falta de um índice remissivo, que sempre acompanha as edições norte-americanas

Antonio Nilson Quezado Cavalcante

\section{Como prever falências}

Por Stephen Charles Kanitz. São Paulo, McGraw-Hill do Brasil, 1978. 176p., il.

O autor deste livro é professor da Universidade de São Paulo e tem uma invejável bagagem econômico-administratıva, tanto em conhecimento teórico quanto prático. Assim, não é de surpreender a ninguém a pequena obra-prima que ele criou com este volume aparentemente despretensioso: como prever falências. Um velho conhecido meu, vendedor com mais de 40 anos de experiência, cunhou a frase "há um cheiro de falência no ar" "quando se referia a certas firmas, e o faro dele era real. Baseava-se em dados, como estoques de matéria-nrima (baixos), atrasos nos pagamentos aos fornecedores, operários com atraso nos pagamentos, proibição de horas extras, aspecto formal e humano do escritório, etc. A quantificação desse faro de vendedor foi realizada por Kanitz.

A primeira surpresa agradável do livro é o fato de o autor ter recorihecido que nem todos os ramos de negóc.o são regidos pelos riesmos incircadores do "cheiro de carniça" da falência. Brilhantemente, mostra que nos bancos o lucro é um bom índice. O livro é àvidido em cinco capítulos:

1. Como prever falências

2.E possivel prever falêncıas?

3. Como calcular os indices
1. Os resultados índice por índice j. Conclusões.

Os métodos empregados pelo autor na avaliação do potencial de solvência ou insolvência baseiamse em estudo simultâneo e paralelo de índices. Num trabalho heróico, o autor digeriu mais de 500 índices da literatura especializada lque é muito resumida na pequena bibliografia) para escolher uns 50 aproximadamente. Não encontro na bibliografia as literaturas francesa e alemã de índices, ambas férteis e indubitavelmente originais, mesmo com eventual duplicação parcial da norte-americana. O autor submete esses índices à prova de aplicação a empresas falidas e não-falidas. 0 estudo é feito com perfeito sentido estatístico, dentro da mais clara metodologia científica, e as conclusões são razoáveis e claras.

O autor parte do princípio de que balanços são enfeitados e, às vezes, adulterados. A novidade é que ele dernonstra estatisticamente o enfeite de balanço (windowdressingl. Permito-me juntar aqui duas observações práticas. Nem sempre adulteração e enfeite resultam da vonicude de mostrar uma boa situação. De fato - de acordo com o embúxador Roberto Campos, em dois artigos publicados no Estado de São Paulo - a Petrobrás usava o expediente de não reavaliar o at.vo para diminuir a depreciação e aumentar os lucros, pois funcionários e diretores tinham e têm participação nos lucros da empresa. ${ }^{1}$

O que não poderá acontecer, nortanto, aos bons principios cor.tábeis, se houver interesse de contadores em aumentar o lucro da empresa $e$, conseqüentemente, também "o deles"?

Um outro caso de windowdressing íoi descoberto pelo resentista no significativamente lucrarivo balanço de uma das grandes empresas quimicas na Bolsa de São Paulo. A empresa, trabalhando 24 por dia, num ramo altamente corrosivo, depreciava tão-somente em 10\% suas instalações. Quanto aos seus edifícios, não depreciava em quase nada a necessidade permanente de sua manutenção por motivo de umidade e fumaças corrosivas. 